\section{Some Aspects of Precambrian Development in East Africa}

THE development of the African continent is often considered as a progressive growth of the stable areas, or cratons. This growth was achieved through consolidation of mobile belts and geosynclines around eight primary cores or nuclei, older than 2,500 m.y. (ref. 1). The area of the ancient nuclei is small compared with that of the present African craton.

For other Precambrian shields, such as the Canadian Shield ${ }^{2}$, it has been suggested that the stable areas grew around primary nuclei. But there is evidence that the process was reversed in East Africa during the Proterozoic, especially in the Upper Proterozoic.

It is now known that mobile belts (or Clifford's vestigeosynclines) developed widely in Africa and are formed mostly by old cratonic material (older than 2,500 m.y.) subjected to tectono-metamorphic rejuvenation at various times. Thus the Archaean rocks in the Limpopo belt, and probably those in the Ubendian-Ruzizian belt, were rejuvenated 2,000 to 1,800 m.y. ago; for those in the Namaqualand belt rejuvenation occurred 1,250 to 900 m.y. ago ${ }^{1,3}$. Extensive areas in Eastern and North-Central Africa underwent the tectonometamorphic rejuvenation during Damaran-Katangan orogeny $(550 \pm 100$ m.y. $)$. It seems that the largest mobile belt of this epoch-the Mozambique belt-is mostly built up of Archaean rocks, as emphasized by the wide distribution of granulite facies (shown in standard survey maps of Kenya and Tanzania, $1: 125,000$ ) uncommon in metamorphic complexes younger than Archaean. Direct transition from the Archaean granites of the Tanganyika and Rodesia shields to the Mozambique gneisses has been established in a number of localities ${ }^{4-6}$. The Archaean Mozambique gneisses extend to the north as far as Ethiopia?.

Besides the older gneisses one can distinguish in the Mozambique belt some metasediments (quartzites, arocosses, limestones and so on) which once formed a cover on the Archaean rocks. In Kenya they were recognized as the Turoka series ${ }^{6}$, which should probably be correlated with the graphitelimestone series of Tanzania ${ }^{8}$ and the Wadera series of southern Ethiopia ${ }^{7}$. The sediments were folded and metamorphosed together with the ancient basement during the Mozambique tectono-metamorphic event.

Since the ancient platform cover is older than Upper Proterozoic (in Ethiopia it acts as a "basement" for the Upper Proterozoic folded belts) and younger than Archaean, its age can be tentatively placed within Lower-Middle Proterozoic. It therefore appears roughly contemporaneous with the platform cover on the cratonic massifs of South Africa. Thus it is probable that in pre-Mozambique (or pre-Pan-African) time the belt was a part of a large Archaean craton together with what now constitutes the Tanganyika, Rhodesia and Kaapwaal cratons. Tectono-metamorphic activation of the old cratonic material led to the formation of the mobile belt which acted as a zone of weakness and instability during the later stages of the geological history. In Karroo time the Mozambique and Zambezi belts controlled the distribution of sedimentation troughs and volcanism. There is some evidence that the separation of Gondwana (or at least the separation of Madagascar from Africa) took place along the Mozambique belt ${ }^{9}$. The Tertiary-Quaternary rifts in East Africa also follow the pattern of the mobile belts, reflecting a new stage of disruption of the African continent.

Thus it is hard to accept that the formation of the Mozambique belt was a "cratonization"; on the contrary, it looks like the beginning of disruption of an ancient Archaean craton. A somewhat similar idea has already been expressed by Anhaeusser et al. ${ }^{3}$. If this conclusion is justified for other mobile belts, as is likely to be the case, the area of the Archaean protocraton could be very large.

One must also remember that many Upper Proterozoic folded belts in Africa (Kibarides, Katangides) are miogeo- synclines apparently formed on the thick granito-gneissic crust. This is shown by the type of sedimentation (mainly terrigenous rocks) and specific character of magmatism (absence of ultrabasic and basic rocks). In some cases the underlying sialic crust could be either Archaean or rejuvenated Archaean, though this is not established.

The following succession of Precambrian events may be suggested at least for a larger part of South and East-Central Africa. First, formation of large Archaean craton (older than 2,500 m.y.); second, accumulation of platform cover over the great part of the craton $(2,500-2,000$ or 1,800 m.y.); third, development of the first mobile belts (Limpopo, Ubenda) marking the beginning of disruption of the protocraton (2,000-1,800 m.y.); fourth, large scale rejuvenation of the ancient basement in the Upper Proterozoic (younger than 1,600 m.y.). Formation of: (a) mobile belts (Mozambique, Zambezi, Namaqualand) and (b) miogeosynclines on the rejuvenated basement (Kibarides, Katangides).

The ancient massifs such as the Tanganyika, Rhodesia and Kaapwaal cratons should be considered not as nuclei but as the relics of a large Archaean craton.

PO Box 5580,

V. KAZMiN

Addis-Ababa,

Ethiopia

Received December 6, 1971.

${ }^{1}$ Clifford, T. N., in African Magmatism and Tectonics (Edinburgh, 1970).

2 Goodwin, A. M., Geol. Assoc. Canada, Proc., 19 (1968).

3 Anhaeusser, C. R., Mason, R., Viljoen, M. J., and Viljoen, R. P., A Reappraisal of Some Aspects of Precambrian Shield Geology, University of the Witwatersrand, Johannesburg, Inf. Circ. No. 49 (1968).

4 Hepworth, J. V., and Kennerley, J. B., Quart.J. Geol. Soc. London, $125,4(1970)$.

5 Jonson, R. L., Bull. Geol. Soc. Amer., 79, 513 (1968).

6 Sanders, L. D., Geology of the Contact Between the Nyanza Shield and the Mozambique Belt in Western Kenya, Ministry of Natural Resources, Geol. Survey of Kenya Bull. No. 7 (1965).

${ }^{7}$ Kazmin, V., Nature, 230, 176 (1971).

${ }^{8}$ Quennel, A. M., Mckinlay, A. C. M., and Aitchen, W. G., Summary of the Geology of Tanganyika, P.I. Introduction and Stratigraphy (Government Printer, Dar es Salaam, 1956).

9 Cox, K. G., in African Magmatism and Tectonics (Edinburgh, (1970).

\section{Major Strike-slip Fault of Late Hercynian Age in Morocco}

IN Morocco, there are two main zones of Hercynian outcrops, one north and one south of the so-called "South Atlastic Fault"1 (Fig. 1). In the southern part, the intensity of folding remains moderate, gradually decreasing southward towards the tabular platform of the Sahara Shield. By contrast, the northern part seems to be the heart of the folded belt: deformation is more marked, with an outstanding development of slaty cleavage and some metamorphism, with several intrusions of granitic plutons.

In the alpine zones of the Middle and High Atlas, these Hercynian units have been deformed again by Cainozoic tectonics, but not intensely enough to obliterate the Hercynian structures.

The principal features of the Hercynian tectonics in most massives are well known. Because of the widespread postHercynian deposits, however, only isolated blocks outcrop in this northern zone, so that the general pattern of the folds has not yet been settled. In this communication we show that, when attempting to restore the pattern of these Hercynian folds, one must take into account the existence of late Hercynian strike-slip faults which altered the original features; and we give a first outline of one of the most important of these strike-slip faults. 